\title{
Optimal Conditions of Immune Complex Transfer Enzyme Immunoassays for Antibody IgGs to HIV-1 Using Recombinant p17, p24, and Reverse Transcriptase as Antigens
}

\author{
Seiichi Hashida, ${ }^{1}$ Setsuko Ishikawa, ${ }^{1}$ Kazuya Hashinaka, ${ }^{1}$ Ichiro Nishikata, ${ }^{1}$ \\ Shinichi Oka, ${ }^{2}$ Kaoru Shimada, ${ }^{2}$ Atsushi Saito, ${ }^{3}$ Akihisa Takamizawa, ${ }^{4}$ \\ Hideo Shinagawa, ${ }^{3}$ and Eiji Ishikawa ${ }^{1 *}$ \\ ${ }^{1}$ Department of Biochemistry, Miyazaki Medical College, Kiyotake, Miyazaki, Japan \\ ${ }^{2}$ Department of Infectious Diseases, Institute of Medical Science, University of Tokyo, Tokyo, Japan \\ ${ }^{3}$ Department of Molecular Microbiology, Research Institute for Microbial Diseases, Osaka University, Osaka, Japan \\ ${ }^{4}$ Kanonji Institute, The Research Foundation for Microbial Diseases of Osaka University, Kanonji, Kagawa, Japan
}

\begin{abstract}
The immune complex transfer enzyme immunoassays for antibody lgGs to p17, p24, and reverse transcriptase (RT) of HIV-1 were tested under various conditions. Antibody lgGs to HIV-1 were reacted for up to $20 \mathrm{hr}$ with 2,4dinitrophenyl-bovine serum albumin-recombinant HIV-1 protein conjugates and recombinant HIV-1 protein- $\beta$-D-galactosidase conjugates, and the immune complexes formed, comprising the three components, were trapped onto polystyrene beads coated with (anti-2,4-dinitrophenyl group) IgG by incubation at $4-30^{\circ} \mathrm{C}$ for up to $2 \mathrm{hr}$ with shaking and were transferred onto polystyrene beads coated with (antihuman IgG $\gamma$-chain) IgG in the presence of excess of $\varepsilon N$-2,4-dinitrophenyl-L-lysine by incubation at $4-30^{\circ} \mathrm{C}$ for up to $2 \mathrm{hr}$ with shaking. When serum randomly collected from an HIV-1 seropositive subject and serum included in an Western blot kit were tested, the formation of the immune complex was almost completed within $1 \mathrm{hr}$ for antibody $\lg \mathrm{G}$ to $\mathrm{p} 17$, within 1-2 $\mathrm{hr}$ for antibody $\lg \mathrm{G}$ to p24 and within $4 \mathrm{hr}$ for antibody lgG to RT. Even for antibody $\lg G$ to $p 17$, however, the immune complex continued to be formed for at least $2 \mathrm{hr}$, when serum samples at early stages of HIV-1 infection were tested. Trapping and transferring of the immune complexes were faster at higher temperatures and were almost completed within $0.5-1.5 \mathrm{hr}$, al-
\end{abstract}

though the amount of the immune complexes trapped and transferred at 25 and $/$ or $30^{\circ} \mathrm{C}$ increased for $0.5-1 \mathrm{hr}$, but subsequently tended to decline. When the formation, trapping, and transferring of the immune complexes were performed for $0.5,1$, and $1 \mathrm{hr}$, respectively, with shaking followed by $1 \mathrm{hr}$ assay of bound $\beta$-D-galactosidase activity, the sensitivities for antibody lgGs to p17, p24, and RT using $10 \mu \mathrm{l}$ of serum samples were similar to or significantly higher than those of the corresponding previous immune complex transfer enzyme immunoassays using $10 \mu \mathrm{l}$ of serum samples, in which the formation, trapping, and transferring of the immune complexes were performed for 3,16 , and $3 \mathrm{hr}$, respectively, without shaking, followed by 2.5 $\mathrm{hr}$ assay of bound $\beta$-D-galactosidase activity, and the sensitivities for antibody IgGs to p17, p24, and RT using $100 \mu \mathrm{l}$ of serum samples were 21-22-fold, 5.5-6.3-fold, and 5.3-6.0-fold, respectively, higher. When each period of time for the formation, trapping, and transferring of the immune complexes was prolonged to up to $4 \mathrm{hr}$, the sensitivities for antibody IgGs to p17, p24, and RT using 100 $\mu \mathrm{l}$ of serum samples were improved 88-93fold, 15-17-fold and 20-24-fold, respectively, as compared with those of the previous ones. J. Clin. Lab. Anal. 12:98-107, 1998. (c) 1998 Wiley-Liss, Inc.

Key words: antibody; human immunodeficiency virus type $1 ;$ p17; 24 ; reverse transcriptase

\section{INTRODUCTION}

Ultrasensitive enzyme immunoassays (immune complex transfer enzyme immunoassays) for antibody IgGs to p17, p24, and reverse transcriptase (RT) of HIV-1 have been developed using recombinant p17, p24, and RT (rp17, rp24, and rRT) as antigens (1-7). The immune complexes, comprising 2,4-
*Correspondence to: Eiji Ishikawa, M.D., Department of Biochemistry, Miyazaki Medical College, Kiyotake, Miyazaki 889-16, Japan.

Received 13 August 1997; Accepted 20 August 1997 
dinitrophenyl-recombinant protein conjugates, antibody $\operatorname{IgGs}$ to HIV- 1 and recombinant protein- $\beta$-D-galactosidase conjugates, were formed by $3 \mathrm{hr}$ incubation and were trapped onto polystyrene beads coated with affinity-purified (anti-2,4-dinitrophenyl group) $\mathrm{IgG}$ by overnight incubation. After washing, the immune complexes were eluted from the polystyrene beads with $\varepsilon N$ 2,4-dinitrophenyl-L-lysine and were transferred to polystyrene beads coated with affinity-purified (antihuman IgG $\gamma$-chain) IgG by $3 \mathrm{hr}$ incubation. Bound $\beta$-D-galactosidase activity was assayed by fluorometry for $2.5 \mathrm{hr}$. The volume of serum samples used was $10 \mu$ l. These immunoassays have made possible diagnosis of HIV-1 infection with urine (1-4) and whole saliva samples $(5,6)$ and have been shown to be more useful as a confirmatory test with higher sensitivities and specificities than Western blotting (7). Notably, antibody IgG to p17 of HIV-1 could be detected as early as or even earlier than antibodies to HIV-1 by conventional methods $(7,8)$. In addition, an ultrasensitive enzyme immunoassay based on a similar principle for p24 antigen of HIV-1 has also been developed $(9,10)$. On the basis of these results, the window period after HIV-1 infection, during which diagnosis of HIV-1 infection is not possible due to the absence of detectable antibodies to HIV-1, has been shortened by simultaneous detection of both p 24 antigen and antibody IgGs to p17 and RT (8). In these immunoassays, however, the period of time used for the immunoreactions involved was considerably long as described above. Recently, it has been made possible to perform more sensitive immune complex transfer enzyme immunoassays for antibody IgG to $\mathrm{p} 17$ within shorter periods of time (15-60 min each for the formation, trapping, and transferring of the immune complex) by incubations for the immunoreactions with shaking using a larger volume of serum samples $(100 \mu \mathrm{l})$ and solid phases with larger surface areas (11).

This report describes optimal conditions of the immune complex transfer enzyme immunoassays for antibody $\operatorname{IgGs}$ to $\mathrm{p} 17$, p24, and reverse transcriptase of HIV-1.

\section{MATERIALS AND METHODS}

\section{Buffer}

The regularly used buffer was $10 \mathrm{mmol} / \mathrm{L}$ sodium phosphate buffer, $\mathrm{pH}$ 7.0, containing $1.0 \mathrm{~g} / \mathrm{L}$ bovine serum albumin (fraction V, Intergen, Purchase, NY), $1.0 \mathrm{mmol} / \mathrm{L} \mathrm{MgCl}_{2}$ and $1.0 \mathrm{~g} / \mathrm{L} \mathrm{NaN}_{3}$ (buffer A).

\section{Recombinant Proteins of HIV-1}

Recombinant reverse transcriptase (rRT), recombinant p17 (rp17) and recombinant p24 (rp24) were produced in Escherichia coli transformed with expression plasmids carrying the corresponding cDNAs and were purified as described previously $(1,12-14)$. The recombinant proviral clone used was pNL4-3 (15), which contained DNA from HIV-1 isolates NY5
(GenBank accession number HIVNL43) and LAV (16), and the sequences for RT, p17, and p24 derived from NY5.

\section{Previous Immune Complex Transfer Enzyme Immunoassays for Antibody IgGs to HIV-1}

Antibody IgGs to p17, p24, and RT of HIV-1 were measured essentially in the same way as described previously (7). An aliquot $(10 \mu \mathrm{l})$ of serum was mixed with $90 \mu \mathrm{l}$ of buffer A containing $0.4 \mathrm{~mol} / \mathrm{L} \mathrm{NaCl}$ and was incubated for $3 \mathrm{hr}$ with $50 \mu \mathrm{l}$ of buffer A containing $0.4 \mathrm{~mol} / \mathrm{L} \mathrm{NaCl}$, inactive $\beta$-D-galactosidase $(50 \mu \mathrm{g})$, and $100 \mathrm{fmol}$ each of 2,4-dinitrophenyl-bovine serum albumin-recombinant HIV-1 protein conjugate and recombinant HIV- 1 protein- $\beta$-D-galactosidase conjugate. To the reaction mixture, two colored polystyrene beads coated with affinity-purified (anti-2,4-dinitrophenyl group) IgG were added, and the incubation was continued for $16 \mathrm{hr}$. The colored polystyrene beads were washed and incubated for $1 \mathrm{hr}$ with two white polystyrene beads coated with affinity-purified (antihuman IgG $\gamma$-chain) IgG in $150 \mu \mathrm{l}$ of buffer A containing $0.1 \mathrm{~mol} /$ $\mathrm{L} \mathrm{NaCl}$ and $1 \mathrm{mmol} / \mathrm{L} \varepsilon N$-2,4-dinitrophenyl-L-lysine. The colored polystyrene beads were removed, and the incubation was continued for $2 \mathrm{hr}$. The incubations were performed at room temperature without shaking. The white polystyrene beads were washed and $\beta$-D-galactosidase activity bound was assayed at $30^{\circ} \mathrm{C}$ for $2.5 \mathrm{hr}$ by fluorometry using 4-methylumbelliferyl- $\beta$ D-galactoside as substrate (17). The fluorescence intensity was measured by adjusting that of $1 \times 10^{-8} \mathrm{~mol} / \mathrm{L}$ 4-methylumbelliferone in $0.1 \mathrm{~mol} / \mathrm{L}$ glycine- $\mathrm{NaOH}$ buffer, $\mathrm{pH} 10.3$ to 100 using $360 \mathrm{~nm}$ for excitation and $450 \mathrm{~nm}$ for emission analysis with a spectrofluorophotometer (F-3010, Hitachi, Tokyo, Japan).

\section{Present Immune Complex Transfer Enzyme Immunoassays for Antibody IgGs to HIV-1}

The present immune complex transfer enzyme immunoassays were performed in the same way as the previous ones described above except for the following modifications. Serum samples $(10 \mu \mathrm{l}$ or $100 \mu \mathrm{l})$ were incubated with the two conjugates and inactive $\beta$-D-galactosidase for up to $20 \mathrm{hr}$ and subsequently with two colored polystyrene beads coated with affinity-purified (anti-2,4-dinitrophenyl group) IgG for up to 2 $\mathrm{hr}$. When $100 \mu \mathrm{l}$ of serum samples was used, the concentration of $\mathrm{NaCl}$ in the final mixture of serum samples and the two conjugates was adjusted to $0.4 \mathrm{~mol} / \mathrm{L}$ assuming that in serum to be $0.15 \mathrm{~mol} / \mathrm{L}$. The colored polystyrene beads after washing were incubated for up to $2 \mathrm{hr}$ with affinity-purified (antihuman IgG $\gamma$-chain) IgG-coated polystyrene beads in the presence of $\varepsilon N$ 2,4-dinitrophenyl-L-lysine. The incubations were performed at 4,25 , and $30^{\circ} \mathrm{C}$ with 180 shakings per min throughout. Bound $\beta$-D-galactosidase activity was assayed at $30^{\circ} \mathrm{C}$ for up to $4 \mathrm{hr}$.

\section{Other Immunological Methods}

The gelatin particle agglutination test for antibodies to HIV-1 was performed using a commercial kit with a lysate of 
HIV-1 as antigen (SERODIA-HIV, Fujirebio, Tokyo, Japan). Western blotting for antibody IgGs to HIV-1 was performed using a commercial kit preblotted with nine proteins of HIV1 (gp160, gp120, p66, p55, p51, gp41, p31, p24, and p17) (Ortho HIV Western Blot Kit, Ortho Diagnostic Systems, Raritan, NJ).

\section{Seroconversion Serum Panels}

Two seroconversion serum panels, SV-0241 and Panel Z, were obtained from North American Biologicals (Miami, FL) and Boston Biomedica (West Bridgewater, MA), respectively.

\section{Serum Samples Randomly Collected From HIV-1 Seronegative and Seropositive Subjects}

Serum samples were randomly collected from 50 HIV-1 seronegative subjects ( 23 males, ages $22-59 \mathrm{yr}$ and $27 \mathrm{fe}-$ males, ages 27-73 yr) and two HIV-1 seropositive subjects (male and female asymptomatic carriers (AC), ages 22 and 39 years) and were stored at $-20^{\circ} \mathrm{C}$ until use. The seronegativity and seropositivity were tested by the gelatin particle agglutination test. The seropositivity was confirmed by Western blotting.

\section{RESULTS AND DISCUSSION}

In the present immune complex transfer enzyme immunoassays for antibody IgGs to HIV-1, the immune complexes comprising 2,4-dinitrophenyl-bovine serum albumin-recombinant HIV-1 protein conjugates, antibody IgGs to HIV-1, and recombinant HIV-1 protein- $\beta$-D-galactosidase conjugates were trapped onto colored polystyrene beads coated with (anti2,4-dinitrophenyl group) IgG and were transferred to white polystyrene beads coated with (antihuman $\operatorname{IgG} \gamma$-chain) $\operatorname{IgG}$ in the presence of excess of $\varepsilon N$-2,4-dinitrophenyl-L-lysine (Fig. 1). Incubations for the immunoreactions were performed at $4-30^{\circ} \mathrm{C}$ with shaking throughout, and $\beta$-D-galactosidase activity bound to the white polystyrene beads was assayed by fluorometry at $30^{\circ} \mathrm{C}$. The period of time required for each immunoreaction and the sensitivity were examined.

\section{Time Courses for the Formation of the Immune Complexes Comprising Antibody IgGs to HIV-1 and the Two Conjugates}

In order to determine the period of time required for the formation of the immune complexes, serum samples containing antibody IgGs to HIV-1 were incubated at room temperature with 2,4-dinitrophenyl-bovine serum albumin-recombinant HIV-1 protein conjugates and recombinant HIV-1 protein- $\beta$ D-galactosidase conjugates at room temperature for up to 20 $\mathrm{hr}$ and subsequently with the colored polystyrene beads for 20 min with shaking (Fig. 2). When serum from an HIV-1 seropositive subject and serum included in an Western blot kit for
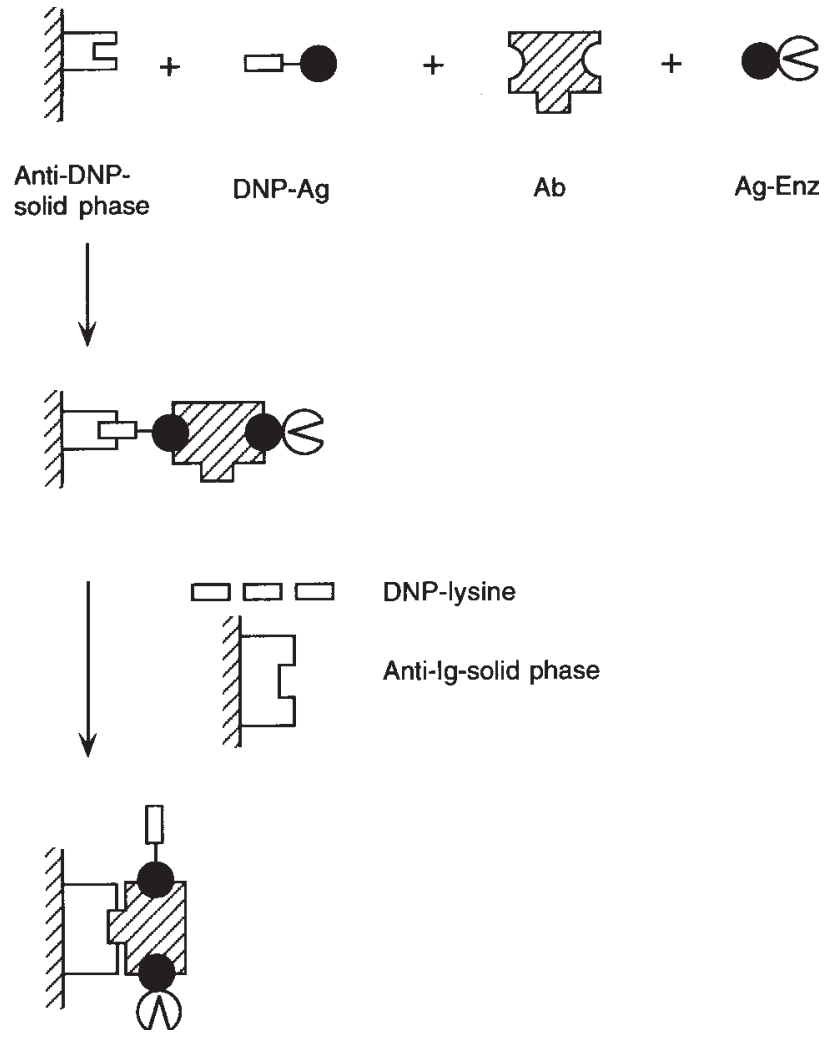

Fig. 1. Immune complex transfer enzyme immunoassay for antibody IgG. DNP: 2,4-dinitrophenyl group. Ag: antigen. Enz: enzyme.

HIV antibody test (Ortho Diagnostic Systems) were tested, $\beta$ D-galactosidase activities bound to the colored polystyrene beads reached values close to the maximum within $1 \mathrm{hr}$ for antibody $\operatorname{IgG}$ to $\mathrm{p} 17$, within $1-2 \mathrm{hr}$ for antibody $\operatorname{IgG}$ to $\mathrm{p} 24$, and within $4 \mathrm{hr}$ for antibody IgG to RT. Even for antibody IgG to $\mathrm{p} 17$, however, bound $\beta$-D-galactosidase activity continued to increase for $1 \mathrm{hr}$, when serum samples in seroconversion serum panels, namely, at early stages of the infection, were tested. Thus the formation of the immune complex was almost completed within $1 \mathrm{hr}$ for antibody IgG to $\mathrm{p} 17$, within $1-2 \mathrm{hr}$ for antibody IgG to p24 and within $4 \mathrm{hr}$ for antibody IgG to $\mathrm{RT}$, although longer periods of time were required with some serum samples at early stages of HIV-1 infection.

\section{Time Courses of Trapping the Immune Complexes Comprising Antibody IgGs to HIV-1 and the Two Conjugates}

On the basis of the above results, serum samples included in the Ortho Western blot kit described above after dilution with serum from an HIV-1 seronegative subject were incubated at room temperature with the two rp17 and rp24 conjugates for $1.5 \mathrm{hr}$ and with the two rRT conjugates for $4 \mathrm{hr}$ and subsequently with the colored polystyrene beads at 4,25 or $30^{\circ} \mathrm{C}$ for up to $2 \mathrm{hr}$ with shaking (Fig. 3). $\beta$-D-Galactosidase activity bound to the colored polystyrene beads at $25^{\circ} \mathrm{C}$ reached 


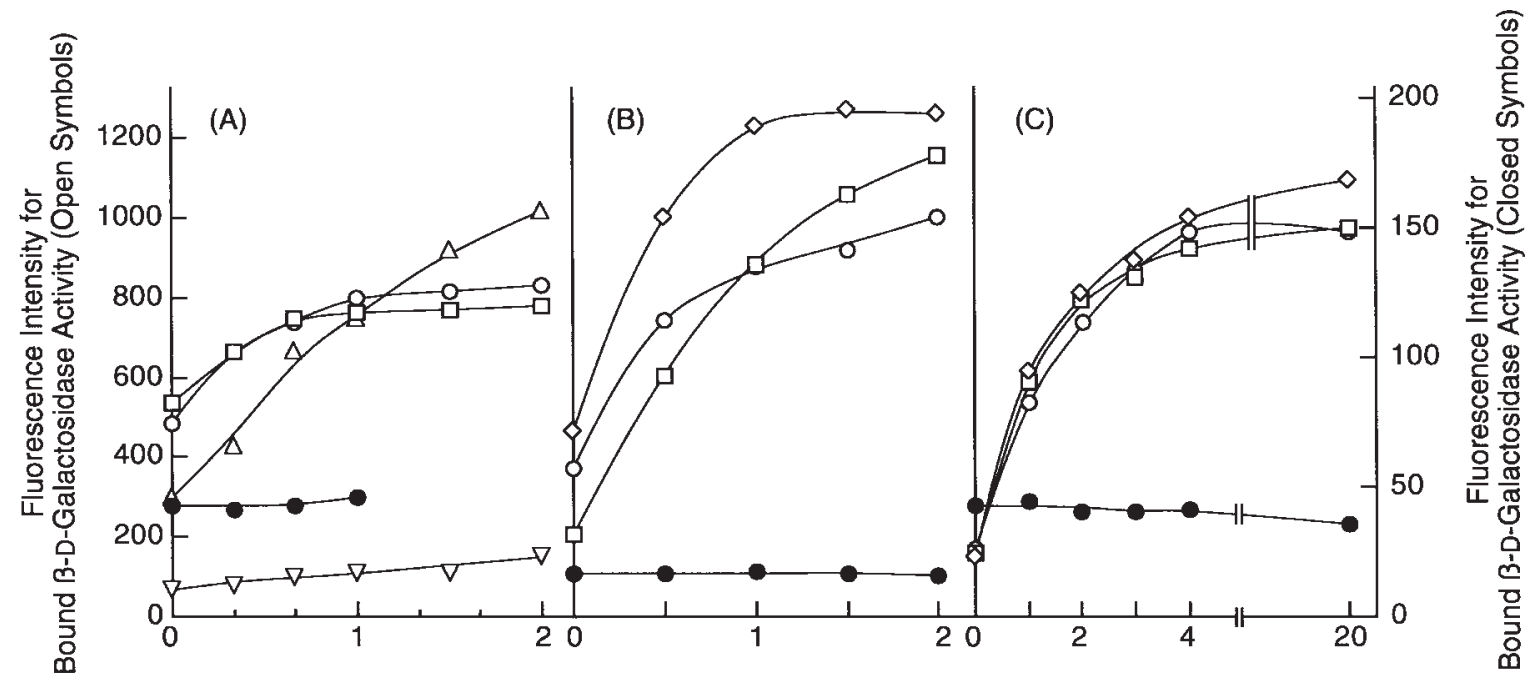

Time for Formation of the Immune Complexes (hr)

Fig. 2. Time course for the formation of the immune complexes comprising 2,4-dinitrophenyl-bovine serum albumin-recombinant HIV-1 protein conjugates, antibodies to HIV-1 proteins and recombinant HIV-1 protein- $\beta$-D-galactosidase conjugates. A. Antibody IgG to p17. B. Antibody IgG to p24. C. Antibody IgG to RT. An aliquot (10 $\mu$ l) of serum samples was incubated at room temperature with 2,4-dinitrophenylbovine serum albumin-recombinant HIV-1 protein conjugate and recombinant HIV-1 protein- $\beta$-D-galactosidase conjugate for up to $20 \mathrm{hr}$ and subsequently with two colored polystyrene beads coated with affinity-purified (anti-2,4-dinitrophenyl group) $\operatorname{IgG}$ for $20 \mathrm{~min}$ with shaking. $\beta$-D-Galactosidase activity bound to the colored polystyrene beads was assayed at $30^{\circ} \mathrm{C}$ for $1 \mathrm{hr}$. Open circles: Serum included in a West-

values close to the maximum within $1-1.5 \mathrm{hr}$ for all the three antibody IgGs. With the rp17 conjugates, $\beta$-D-galactosidase activity bound at $4{ }^{\circ} \mathrm{C}$ increased more slowly and reached values close to the maximum within $2 \mathrm{hr}$, and that bound at $30^{\circ} \mathrm{C}$ increased faster but decreased after $1 \mathrm{hr}$. Thus trapping of the immune complexes at $25^{\circ} \mathrm{C}$ was completed within $1-1.5 \mathrm{hr}$ for all the three antibody IgGs. Trapping of the immune complex for antibody $\operatorname{IgG}$ to $\mathrm{p} 17$ was slower at $4^{\circ} \mathrm{C}$ and faster at $30^{\circ} \mathrm{C}$, and the immune complex trapped at $25^{\circ} \mathrm{C}$ and $30^{\circ} \mathrm{C}$ was lost slowly after $1 \mathrm{hr}$ and $0.5 \mathrm{hr}$, respectively. $\beta$-D-Galactosidase activities bound nonspecifically in the absence of antibody IgGs to HIV-1 were higher at higher temperatures and reached the maximal values within $0.5-1 \mathrm{hr}$.

\section{Time Courses of Transferring the Immune Complexes Comprising Antibody IgGs to HIV-1 and the Two Conjugates}

On the basis of the above results, serum samples included in the Ortho Western blot kit described above after dilution with serum from an HIV-1 seronegative subject were incubated at room temperature with the two rp17 and rp24 conjugates for $1.5 \mathrm{hr}$ and with the two rRT conjugates for $4 \mathrm{hr}$ and subsequently with the colored polystyrene beads for $1 \mathrm{hr}$ with ern blot kit for HIV antibody test (Ortho Diagnostic Systems) was diluted 5,000-fold (A), 2,000-fold (B), and 400-fold (C) with serum from an HIV-1 seronegative subject. Open squares: Serum from an HIV-1 seropositive subject was diluted 10,000-fold (A), 5,000-fold (B), and 2,500-fold (C) with serum from an HIV-1 seronegative subject. Open rhombuses: Serum from another HIV-1 seropositive subject was diluted 2,000-fold (B and C) with serum from an HIV-1 seronegative subject. Open triangles: Serum on the day of 27 in panel Z, Boston Biomedica, was used without dilution. Open counter triangles: Serum on the day of 14 in panel SV-0241, North American Biologicals, was used without dilution. Closed circles: Nonspecific rabbit serum was substituted for human serum samples.

shaking. The colored polystyrene beads after washing were incubated with the white polystyrene beads in the presence of $\varepsilon N$-2,4-dinitrophenyl-L-lysine at 4,25 and $30^{\circ} \mathrm{C}$ for up to $2 \mathrm{hr}$ with shaking (Fig. 4). Bound $\beta$-D-galactosidase activities increased faster at higher temperatures, reached values close to the maximum within $1-1.5 \mathrm{hr}$ at 4 to $30^{\circ} \mathrm{C}$, and decreased after $1 \mathrm{hr}$ at $30^{\circ} \mathrm{C}$ for antibody IgG to p17 and after $1.5 \mathrm{hr}$ for antibody IgG to RT. Thus transferring of the immune complexes was completed within 1-1.5 hr for all the three antibody IgGs, although faster at higher temperatures. The immune complexes trapped at $25-30^{\circ} \mathrm{C}$ were lost after $1-1.5 \mathrm{hr}$ for antibody IgGs to p17 and RT. $\beta$-D-Galactosidase activities bound nonspecifically in the absence of antibody IgGs to HIV-1 were very low.

\section{Sensitivities of the Present Immune Complex Transfer Enzyme Immunoassays for Antibody IgGs to HIV-1}

Serum randomly collected from an HIV-1 seropositive subject was serially diluted with serum from an HIV-1 seronegative subject, and the diluted serum samples were tested by the present immune complex transfer enzyme immunoassays under various conditions. The period of time for each immunoreaction 


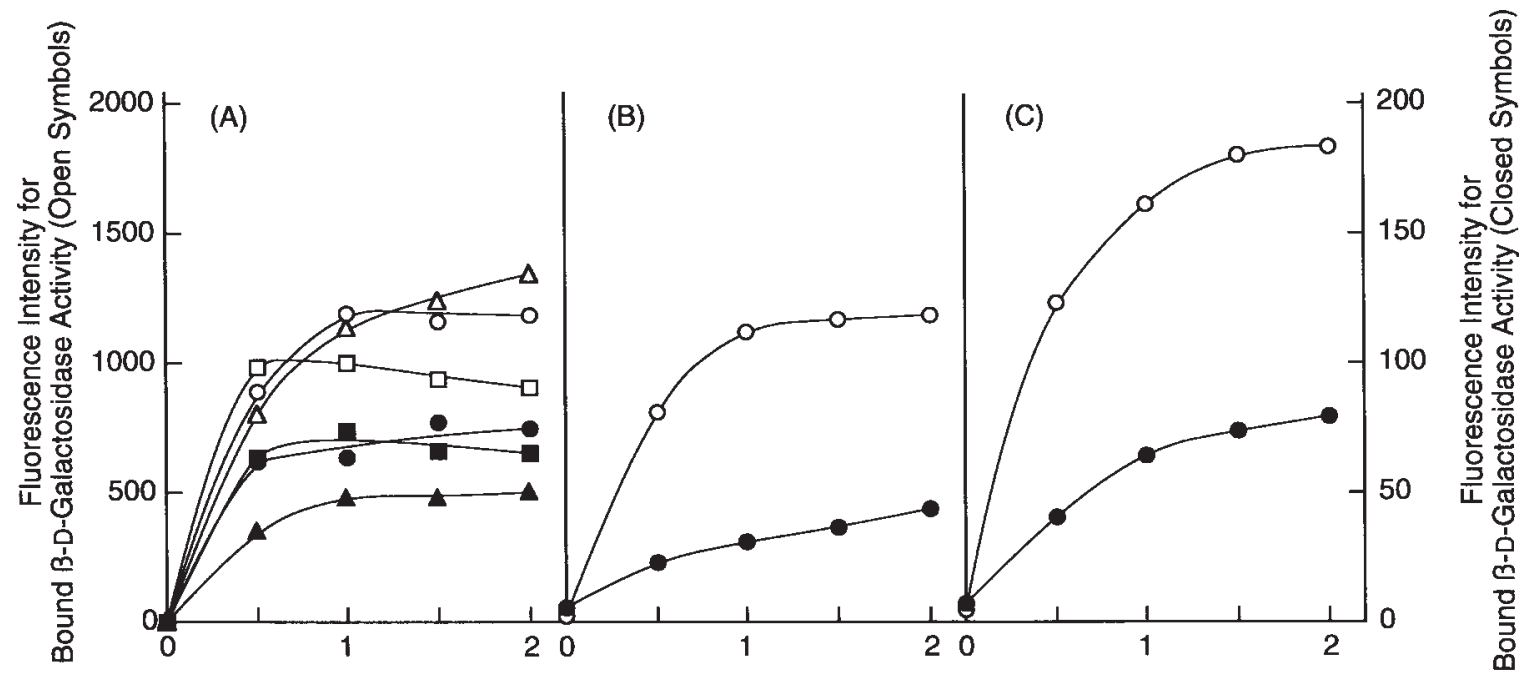

Time for Trapping of the Immune Complexes (hr)

Fig. 3. Time course for trapping of the immune complexes. A. Antibody IgG to p17. B. Antibody IgG to p24. C. Antibody IgG to RT. An aliquot (10 $\mu 1)$ of serum samples was incubated at room temperature with 2,4dinitrophenyl-bovine serum albumin-recombinant HIV-1 protein conjugates and recombinant HIV-1 protein- $\beta$-D-galactosidase conjugates for $1.5 \mathrm{hr}$ (A and $\mathrm{B}$ ) and $4 \mathrm{hr}(\mathrm{C})$ and subsequently with colored polystyrene beads coated with affinity-purified (anti-2,4-dinitrophenyl group) $\mathrm{IgG}$ at $4^{\circ} \mathrm{C}$ (triangles), $25^{\circ} \mathrm{C}$ (circles) and $30^{\circ} \mathrm{C}$ (squares) for up to $2 \mathrm{hr}$. $\beta$-D-Galactosidase activity bound to the colored polystyrene beads was assayed at $30^{\circ} \mathrm{C}$ for $1 \mathrm{hr}$. Open symbols: Serum included in the Ortho Western blot kit used in Figure 2 was diluted 5,000-fold (A), 2,000-fold (B), and 400-fold (C) with serum from an HIV-1 seronegative subject. Closed symbols: Nonspecific rabbit serum was substituted for human serum samples.

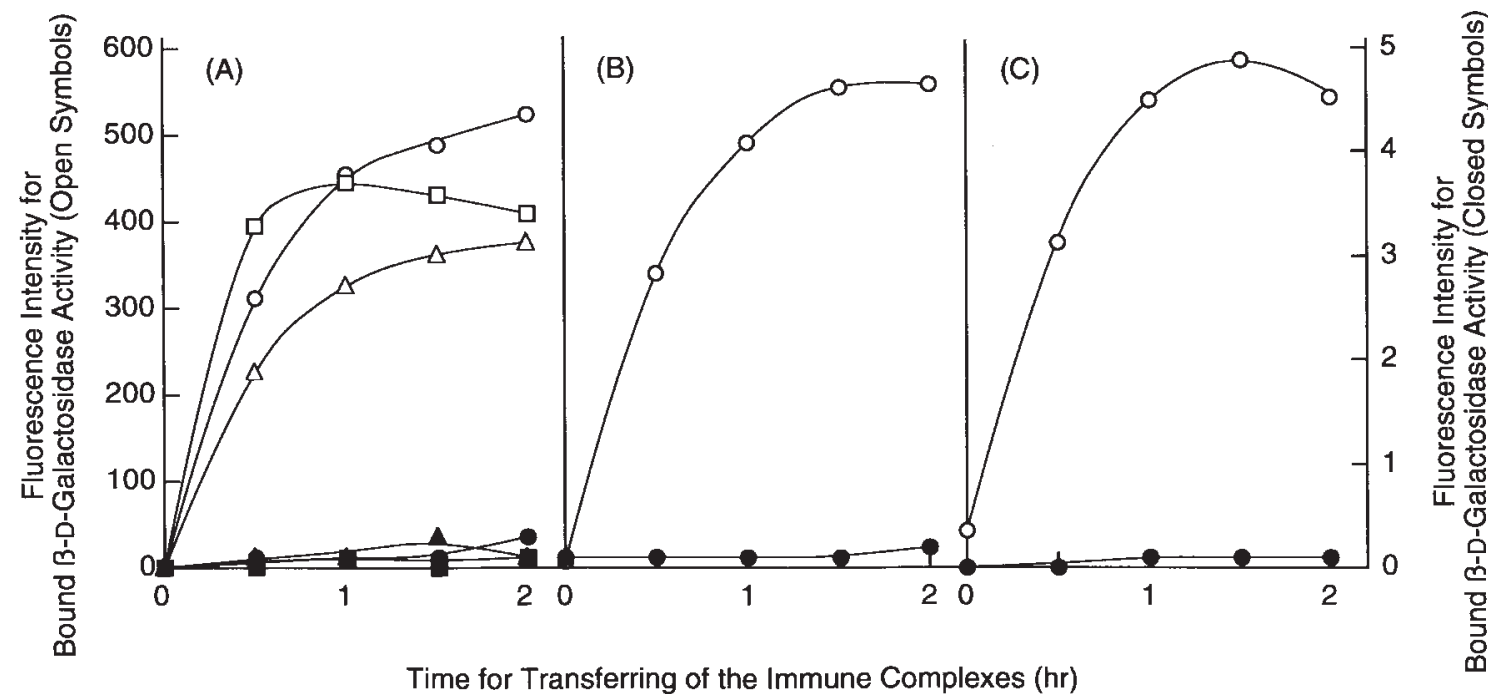

Fig. 4. Time course for transferring of the immune complexes. A. Antibody IgG to p17. B. Antibody IgG to p24. C. Antibody IgG to RT. An aliquot $(10 \mu \mathrm{l})$ of serum samples was incubated at room temperature with 2,4-dinitrophenyl-bovine serum albumin-recombinant HIV-1 protein conjugates and recombinant HIV-1 protein- $\beta$-D-galactosidase conjugates for 1.5 $\mathrm{hr}(\mathrm{A}$ and $\mathrm{B})$ and $4 \mathrm{hr}(\mathrm{C})$ and subsequently with colored polystyrene beads coated with (anti-2,4-dinitrophenyl group) IgG for $1 \mathrm{hr}$. The colored polystyrene beads after washing were incubated with white polystyrene beads coated with (antihuman $\operatorname{IgG} \gamma$-chain) $\mathrm{IgG}$ in the presence of $\varepsilon N$-2,4dinitrophenyl-L-lysine at $4^{\circ} \mathrm{C}$ (triangles), $25^{\circ} \mathrm{C}$ (circles), and $30^{\circ} \mathrm{C}$ (squares) for up to $2 \mathrm{hr}$. $\beta$-D-Galactosidase activity bound to the white polystyrene beads was assayed at $30^{\circ} \mathrm{C}$ for $1 \mathrm{hr}$. Open symbols: Serum included in the Ortho Western blot kit used in Figure 2 was diluted 5,000-fold (A), 2,000fold (B), and 400-fold (C) with serum from an HIV-1 seronegative subject. Closed symbols: Nonspecific rabbit serum was substituted for human serum samples. 
TABLE 1. Signal by Previous and Present Immune Complex Transfer Enzyme Immunoassays for Antibody IgG to p17 $^{\mathrm{a}}$

\begin{tabular}{|c|c|c|c|c|c|c|c|c|c|c|c|c|c|c|c|}
\hline \multirow{4}{*}{$\begin{array}{l}\text { Immune } \\
\text { complex } \\
\text { transfer } \\
\text { enzyme } \\
\text { immuno- } \\
\text { assay }\end{array}$} & \multicolumn{5}{|c|}{ Condition of immunoassay } & \multicolumn{10}{|c|}{ Signal (fluorescence intensity of bound $\beta$-D-galactosidase activity) } \\
\hline & \multirow{3}{*}{$\begin{array}{l}\text { Volume } \\
\text { of } \\
\text { diluted } \\
\text { serum } \\
\text { samples }\end{array}$} & \multicolumn{4}{|c|}{ Time for } & \multirow{3}{*}{$\begin{array}{l}\text { Serum } \\
\text { from HIV-1 } \\
\text { seronegative } \\
\text { subjects } \\
(\mathrm{n}=50)\end{array}$} & \multirow{2}{*}{\multicolumn{9}{|c|}{$\begin{array}{l}\text { Dilution of serum from an HIV-1 seropositive subject } \\
\text { with serum from an HIV-1 seronegative subject (-fold) }\end{array}$}} \\
\hline & & \multirow{2}{*}{$\begin{array}{l}\text { formation } \\
\text { of the } \\
\text { immune } \\
\text { complex }\end{array}$} & \multirow{2}{*}{$\begin{array}{l}\text { trapping } \\
\text { of the } \\
\text { immune } \\
\text { complex }\end{array}$} & \multirow{2}{*}{$\begin{array}{l}\text { transfer- } \\
\text { ring of the } \\
\text { immune } \\
\text { complex }\end{array}$} & \multirow{2}{*}{$\begin{array}{l}\text { assay } \\
\text { of bound } \\
\text { enzyme } \\
\text { activity }\end{array}$} & & & & & & & & & & \\
\hline & & & & & & & $10^{8}$ & $3 \times 10^{7}$ & $10^{7}$ & $3 \times 10^{6}$ & $10^{6}$ & $3 \times 10^{5}$ & $10^{5}$ & $10^{3}$ & $3 \times 10^{2}$ \\
\hline & $\mu 1$ & $\mathrm{hr}$ & $\mathrm{hr}$ & $\mathrm{hr}$ & $\mathrm{hr}$ & $\begin{array}{l}\text { mean } \pm \mathrm{SD} \\
\text { (range) }\end{array}$ & & & & & & & & & \\
\hline $\begin{array}{c}\text { Previous, } \\
\text { without } \\
\text { shaking }\end{array}$ & 10 & 3 & 16 & 3 & 2.5 & $\begin{array}{l}0.3 \pm 0.1 \\
(0.1-0.9)\end{array}$ & 0.2 & 0.5 & 0.6 & 0.7 & 1.6 & $4.2(1.0)$ & $14(1.0)$ & NT & NT \\
\hline \multirow{5}{*}{$\begin{array}{l}\text { Present, } \\
\text { with } \\
\text { shaking }\end{array}$} & 10 & 0.5 & 1 & 1 & 1 & $\begin{array}{l}0.1 \pm 0.1 \\
(0.1-0.4)\end{array}$ & 0.1 & 0.2 & 0.6 & 1.6 & 4.8 & $14(3.6)$ & $44(3.2)$ & NT & NT \\
\hline & 10 & 0.5 & 1.5 & 1.5 & 2 & - & 0.3 & 0.4 & 1.1 & 2.8 & 9.6 & $27(6.9)$ & $90(6.6)$ & NT & NT \\
\hline & 100 & 0.5 & 1 & 1 & 1 & $\begin{array}{l}0.2 \pm 0.1 \\
(0.0-0.5)\end{array}$ & 0.4 & 0.9 & 2.7 & 8.0 & 31 & $83(21)$ & $302(22)$ & NT & NT \\
\hline & 100 & 0.5 & 1.5 & 1.5 & 2 & $\begin{array}{l}0.3 \pm 0.1 \\
(0.1-0.7)\end{array}$ & 1.6 & 2.5 & 7.4 & 19 & 66 & $201(51)$ & $621(45)$ & NT & NT \\
\hline & 100 & 0.5 & 1.5 & 1.5 & 4 & $\begin{array}{l}0.4 \pm 0.2 \\
(0.1-0.9)\end{array}$ & 1.5 & 3.8 & 13 & 36 & 118 & 364 (93) & $1212(88)$ & NT & NT \\
\hline $\begin{array}{l}\text { Western } \\
\text { blotting } \\
\text { for p17 } \\
\text { band }\end{array}$ & - & - & - & - & - & NT & NT & NT & NT & NT & - & - & - & - & + \\
\hline
\end{tabular}

${ }^{\mathrm{a}}$ Values in parentheses are the ratios of the signals by the present immune complex transfer enzyme immunoassays to those by the previous one.

NT: not tested. 
TABLE 2. Signal by Previous and Present Immune Complex Transfer Enzyme Immunoassays for Antibody IgG to p24

\begin{tabular}{|c|c|c|c|c|c|c|c|c|c|c|c|c|c|c|}
\hline \multirow{4}{*}{$\begin{array}{l}\text { Immune } \\
\text { complex } \\
\text { transfer } \\
\text { enzyme } \\
\text { immuno- } \\
\text { assay }\end{array}$} & \multicolumn{5}{|c|}{ Condition of immunoassay } & \multicolumn{9}{|c|}{ Signal (fluorescence intensity of bound $\beta$-D-galactosidase activity) } \\
\hline & \multirow{3}{*}{$\begin{array}{l}\text { Volume } \\
\text { of } \\
\text { diluted } \\
\text { serum } \\
\text { samples }\end{array}$} & \multicolumn{4}{|c|}{ Time for } & \multirow{3}{*}{$\begin{array}{l}\text { Serum } \\
\text { from HIV-1 } \\
\text { seronegative } \\
\text { subjects } \\
(\mathrm{n}=50)\end{array}$} & \multirow{2}{*}{\multicolumn{8}{|c|}{$\begin{array}{l}\text { Dilution of serum from an HIV-1 seropositive subject } \\
\text { with serum from an HIV-1 seronegative subject (-fold) }\end{array}$}} \\
\hline & & \multirow{2}{*}{$\begin{array}{l}\text { formation } \\
\text { of the } \\
\text { immune } \\
\text { complex }\end{array}$} & \multirow{2}{*}{$\begin{array}{l}\text { trapping } \\
\text { of the } \\
\text { immune } \\
\text { complex }\end{array}$} & \multirow{2}{*}{$\begin{array}{l}\text { transfer- } \\
\text { ring of the } \\
\text { immune } \\
\text { complex }\end{array}$} & \multirow{2}{*}{$\begin{array}{l}\text { assay } \\
\text { of bound } \\
\text { enzyme } \\
\text { activity }\end{array}$} & & & & & & & & & \\
\hline & & & & & & & $10^{8}$ & $3 \times 10^{7}$ & $10^{7}$ & $3 \times 10^{6}$ & $10^{6}$ & $3 \times 10^{5}$ & $10^{5}$ & $3 \times 10^{3}$ \\
\hline & $\mu 1$ & $\mathrm{hr}$ & $\mathrm{hr}$ & $\mathrm{hr}$ & $\mathrm{hr}$ & $\begin{array}{l}\text { mean } \pm \mathrm{SD} \\
\text { (range) }\end{array}$ & & & & & & & & \\
\hline $\begin{array}{r}\text { Previous, } \\
\text { without } \\
\text { shaking }\end{array}$ & 10 & 3 & 16 & 3 & 2.5 & $\begin{array}{l}0.3 \pm 0.1 \\
(0.1-0.9)\end{array}$ & 0.5 & 0.7 & 1.4 & 2.5 & $9.0(1.0)$ & $25(1.0)$ & $76(1.0)$ & NT \\
\hline \multirow{4}{*}{$\begin{array}{l}\text { Present, } \\
\text { with } \\
\text { shaking }\end{array}$} & 10 & 0.5 & 1 & 1 & 1 & $\begin{array}{l}0.3 \pm 0.1 \\
(0.1-0.6)\end{array}$ & 0.3 & 0.5 & 1.2 & 3.1 & $9.6(1.1)$ & $29(1.1)$ & $96(1.3)$ & NT \\
\hline & 10 & 1.5 & 1.5 & 1.5 & 2 & $\begin{array}{l}0.5 \pm 0.1 \\
(0.3-0.7)\end{array}$ & 1.0 & 1.6 & 3.2 & 8.0 & $25(2.8)$ & $73(2.9)$ & $241(3.2)$ & NT \\
\hline & 100 & 0.5 & 1 & 1 & 1 & $\begin{array}{l}0.2 \pm 0.1 \\
(0-0.6)\end{array}$ & 1.2 & 2.2 & 5.6 & 15 & $49(5.5)$ & $142(5.7)$ & $479(6.3)$ & NT \\
\hline & 100 & 1.5 & 1.5 & 1.5 & 2 & $\begin{array}{l}0.5 \pm 0.2 \\
(0-1.1)\end{array}$ & 3.5 & 6.4 & 15 & 42 & $133(15)$ & 391 (16) & 1259 (17) & NT \\
\hline $\begin{array}{l}\text { Western } \\
\text { blotting } \\
\text { for p24 } \\
\text { band }\end{array}$ & - & - & - & - & - & NT & NT & NT & NT & NT & - & - & - & + \\
\hline
\end{tabular}

${ }^{\mathrm{a}}$ Values in parentheses are the ratios of the signals by the present immune complex transfer enzyme immunoassays to those by the previous one.

NT: not tested. 
TABLE 3. Signal by Previous and Present Immune Complex Transfer Enzyme Immunoassays for Antibody IgG to RT

\begin{tabular}{|c|c|c|c|c|c|c|c|c|c|c|c|c|c|c|c|}
\hline \multirow{4}{*}{$\begin{array}{l}\text { Immune } \\
\text { complex } \\
\text { transfer } \\
\text { enzyme } \\
\text { immuno- } \\
\text { assay }\end{array}$} & \multicolumn{5}{|c|}{ Condition of immunoassay } & \multicolumn{10}{|c|}{ Signal (fluorescence intensity of bound $\beta$-D-galactosidase activity) } \\
\hline & \multirow{3}{*}{$\begin{array}{l}\text { Volume } \\
\text { of } \\
\text { diluted } \\
\text { serum } \\
\text { samples } \\
\end{array}$} & \multicolumn{4}{|c|}{ Time for } & \multirow{3}{*}{$\begin{array}{l}\text { Serum } \\
\text { from HIV-1 } \\
\text { seronegative } \\
\text { subjects } \\
(\mathrm{n}=50)\end{array}$} & \multirow{2}{*}{\multicolumn{9}{|c|}{$\begin{array}{l}\text { Dilution of serum from an HIV-1 seropositive subject } \\
\text { with serum from an HIV-1 seronegative subject (-fold) }\end{array}$}} \\
\hline & & \multirow{2}{*}{$\begin{array}{l}\text { formation } \\
\text { of the } \\
\text { immune } \\
\text { complex }\end{array}$} & \multirow{2}{*}{$\begin{array}{l}\text { trapping } \\
\text { of the } \\
\text { immune } \\
\text { complex }\end{array}$} & \multirow{2}{*}{$\begin{array}{l}\text { transfer- } \\
\text { ring of the } \\
\text { immune } \\
\text { complex }\end{array}$} & \multirow{2}{*}{$\begin{array}{l}\text { assay } \\
\text { of bound } \\
\text { enzyme } \\
\text { activity }\end{array}$} & & & & & & & & & & \\
\hline & & & & & & & $10^{7}$ & $3 \times 10^{6}$ & $10^{6}$ & $3 \times 10^{5}$ & $10^{5}$ & $3 \times 10^{4}$ & $10^{4}$ & $10^{3}$ & $3 \times 10^{2}$ \\
\hline & $\mu 1$ & $\mathrm{hr}$ & $\mathrm{hr}$ & $\mathrm{hr}$ & $\mathrm{hr}$ & $\begin{array}{l}\text { mean } \pm \text { SD } \\
\text { (range) }\end{array}$ & & & & & & & & & \\
\hline $\begin{array}{c}\text { Previous, } \\
\text { without } \\
\text { shaking }\end{array}$ & 10 & 3 & 16 & 3 & 2.5 & $\begin{array}{l}0.8 \pm 0.2 \\
(0.5-1.4)\end{array}$ & 0.9 & 1.1 & 1.4 & 2.3 & 4.3 & $12(1.0)$ & $33(1.0)$ & NT & NT \\
\hline \multirow{4}{*}{$\begin{array}{l}\text { Present, } \\
\text { with } \\
\text { shaking }\end{array}$} & 10 & 0.5 & 1 & 1 & 1 & $\begin{array}{l}0.6 \pm 0.1 \\
(0.3-0.8)\end{array}$ & 0.8 & 0.9 & 1.2 & 2.0 & 5.0 & $15(1.3)$ & $43(1.3)$ & NT & NT \\
\hline & 10 & 4 & 1.5 & 1.5 & 2 & $\begin{array}{l}0.9 \pm 0.2 \\
(0.5-1.2)\end{array}$ & 1.6 & 1.9 & 3.3 & 6.0 & 16 & $46(3.9)$ & $146(4.4)$ & NT & NT \\
\hline & 100 & 0.5 & 1 & 1 & 1 & $\begin{array}{l}0.6 \pm 0.1 \\
(0.4-0.9)\end{array}$ & 0.8 & 1.1 & 2.4 & 6.5 & 19 & $60(5.3)$ & $196(6.0)$ & NT & NT \\
\hline & 100 & 4 & 1.5 & 1.5 & 2 & $\begin{array}{l}0.9 \pm 0.2 \\
(0.6-1.4)\end{array}$ & 2.1 & 3.5 & 9.2 & 24 & 78 & $229(20)$ & 788 (24) & NT & NT \\
\hline $\begin{array}{l}\text { Western } \\
\text { blotting } \\
\text { for p66 } \\
\text { band }\end{array}$ & - & - & - & - & - & NT & NT & NT & - & - & - & - & - & \pm & + \\
\hline
\end{tabular}

${ }^{\mathrm{a}}$ Values in parentheses are the ratios of the signals by the present immune complex transfer enzyme immunoassays to those by the previous one. NT: not tested. 
and the assay of bound $\beta$-D-galactosidase activity and the volume of the diluted serum samples were varied. However, the incubation for each immunoreaction was performed at room temperature with shaking and bound $\beta$-D-galactosidase activity was assayed at $30^{\circ} \mathrm{C}$ throughout. The signal (the fluorescence intensity for $\beta$-D-galactosidase activity bound to white polystyrene beads coated with affinity-purified (anti-human IgG $\gamma$-chain) $\operatorname{IgG}$ ) and the sensitivity were compared with those by the previous immune complex transfer enzyme immunoassays using $10 \mu \mathrm{l}$ of the diluted serum samples, in which the immune complexes were formed, trapped, and transferred at room temperature for $3 \mathrm{hr}, 16 \mathrm{hr}$, and $3 \mathrm{hr}$, respectively, without shaking and bound $\beta$-D-galactosidase activity was assayed at $30^{\circ} \mathrm{C}$ for $2.5 \mathrm{hr}$ (Tables 1, 2, and 3).

With $10 \mu \mathrm{l}$ of serum samples, the signals for the diluted serum samples from an HIV-1 seropositive subject by the present immune complex transfer enzyme immunoassays of antibody IgGs to p17, p24, and RT were 3.2-3.6-fold, 1.11.3-fold, and 1.3-fold, respectively, higher than those by the corresponding previous immune complex transfer enzyme immunoassays, even when the formation, trapping, and transferring of the immune complexes were performed for $0.5,1$ and $1 \mathrm{hr}$, respectively, with $1 \mathrm{hr}$ assay of bound $\beta$-D-galactosidase activity, and were 6.6-6.9-fold, 2.8-3.2-fold, and 3.94.4-fold, respectively, higher, when the periods of time for the formation, trapping, and transferring of the immune complexes and the assay of bound $\beta$-D-galactosidase activity were prolonged to up to $4 \mathrm{hr}$. The signals for serum samples from HIV-1 seronegative subjects were even lower than those by the previous immune complex transfer enzyme immunoassays. As a result, the sensitivities for antibody IgGs to p17, p24, and RT were improved almost to the same extents as the signals were enhanced and were 10,000-fold, 3,00010,000-fold, and 1,000-3,000-fold, respectively, higher than those of Western blotting for p17, p24, and p66 (a subunit of RT) bands.

With $100 \mu 1$ of serum samples, the signals for the diluted serum samples from an HIV-1 seropositive subject by the present immune complex transfer enzyme immunoassays of antibody IgGs to p17, p24, and RT, were 21-22-fold, 5.5-6.3-fold, and 5.3-6.0-fold, respectively, higher than those by the corresponding previous immune complex transfer enzyme immunoassays, even when the formation, trapping, and transferring of the immune complexes were performed for $0.5,1$ and $1 \mathrm{hr}$, respectively, with $1 \mathrm{hr}$ assay of bound $\beta$-D-galactosidase activity and were 88-93-fold, 15-17-fold, and 20-24-fold, respectively, higher, when the periods of time for the formation, trapping, and transferring of the immune complexes and the assay of bound $\beta$-Dgalactosidase activity were prolonged to up to $4 \mathrm{hr}$. The signals for serum samples from HIV-1 seronegative subjects were even lower than those by the previous immune complex transfer enzyme immunoassays. As a result, the sensitivities for antibody IgGs to p17, p24, and RT were improved almost to the same extents as the signals were enhanced and were 30,000-100,000-fold, 10,000-30,000fold, and 3,000-10,000-fold, respectively, higher than those of Western blotting for p17, p24, and p66 bands.

\section{REFERENCES}

1. Hashida S, Hirota K, Hashinaka K, et al: Detection of antibody IgG to HIV-1 in urine by sensitive enzyme immunoassay (immune complex transfer enzyme immunoassay) using recombinant proteins as antigens for diagnosis of HIV-1 infection. J Clin Lab Anal 7:353-364, 1993.

2. Hashida S, Hashinaka K, Hirota K, et al: Detection of antibody IgG to HIV-1 in urine by ultrasensitive enzyme immunoassay (immune complex transfer enzyme immunoassay) using recombinant p24 as antigen for diagnosis of HIV-1 infection. J Clin Lab Anal 8:86-95, 1994.

3. Hashinaka K, Hashida S, Hirota K, et al: Detection of anti-human immunodeficiency virus type 1 (HIV-1) immunoglobulin $\mathrm{G}$ in urine by an ultrasensitive enzyme immunoassay (immune complex transfer enzyme immunoassay) with recombinant reverse transcriptase as an antigen. $J$ Clin Microbiol 32:819-822, 1994.

4. Hashida S, Hashinaka K, Saitoh A, et al: Diagnosis of HIV-1 infection by detection of antibody IgG to HIV-1 in urine with ultrasensitive enzyme immunoassay (immune complex transfer enzyme immunoassay) using recombinant proteins as antigens. J Clin Lab Anal 8:237246, 1994.

5. Ishikawa S, Hashida S, Hashinaka K, et al: Diagnosis of HIV-1 infection with whole saliva by detection of antibody IgG to HIV-1 with ultrasensitive enzyme immunoassay using recombinant reverse transcriptase as antigen. J Acquir Immune Defic Syndr Human Retrovirol 10:41-47, 1995.

6. Ishikawa S, Hashida S, Hashinaka K, et al: Whole saliva dried on filter paper for diagnosis of HIV-1 infection by detection of antibody IgG to HIV-1 with ultrasensitive enzyme immunoassay using recombinant reverse transcriptase as antigen. J Clin Lab Anal 10:35-41, 1996.

7. Hashida S, Hashinaka K, Nishikata I, et al: Immune complex transfer enzyme immunoassay that is more sensitive and specific than Western blotting for detection of antibody immunoglobulin $\mathrm{G}$ to human immunodeficiency virus type 1 in serum with recombinant pol and gag proteins as antigens. Clin Diag Lab Immunol 2:535-541, 1995.

8. Hashida S, Hashinaka K, Nishikata I, et al: Shortening of the window period in diagnosis of HIV-1 infection by simultaneous detection of p24 antigen and antibody IgG to p17 and reverse transcriptase in serum with ultrasensitive enzyme immunoassay. $J$ Virol Methods 62:4353, 1996.

9. Hashida S, Hashinaka K, Nishikata I, et al: Measurement of human immunodeficiency virus type 1 p24 in serum by an ultrasensitive enzyme immunoassay, the two-site immune complex transfer enzyme immunoassay. J Clin Microbiol 33:298-303, 1995.

10. Hashida S, Hashinaka K, Nishikata I, et al: Ultrasensitive and more specific enzyme immunoassay (immune complex transfer enzyme immunoassay) for p24 antigen of HIV-1 in serum using affinity-purified rabbit anti-p24 Fab' and monoclonal mouse anti-p24 Fab’. J Clin Lab Anal 10:302-307, 1996.

11. Ishikawa S, Hashida S, Hashinaka K, et al: More sensitive immune complex transfer enzyme immunoassay for antibody IgG to p17 of HIV-1 with shorter incubation time for immunoreactions and larger volumes of serum samples. J Clin Lab Anal 11:244-250, 1997.

12. Saitoh A, Iwasaki H, Nakata A, Adachi A, Shinagawa H: Overproduction of human immunodeficiency virus type I reverse transcriptase in Escherichia coli and purification of the enzyme. Microbiol Immunol 34:509-521, 1990.

13. Saitoh A, Tanaka N, Nakata A, Ikuta K, Shinagawa H: A unique mono- 
clonal antibody that recognizes mature $\mathrm{p} 17$ of HIV-1 but not its precursor. Microbiol Immunol 36:105-111, 1992.

14. Tanaka N, Saitoh A, Nakata A, Shinagawa H: A simple method for overproduction and purification of $\mathrm{p} 24$ gag protein of human immunodeficiency virus tyep 1. Microbiol Immunol 36:823-831, 1992.

15. Adachi A, Gendelman HE, Koenig S, et al: Production of acquired immunodeficiency syndrome-associated retrovirus in human and nonhu- man cells transfected with an infectious molecular clone.J Virol 59:284291, 1986.

16. Wain-Hobson S, Sonigo P, Danos O, Cole S, Alizon M: Nucleotide sequence of the AIDS virus, LAV. Cell 40:9-17, 1985.

17. Imagawa $M$, Hashida $S$, Ohta $Y$, Ishikawa E: Evaluation of $\beta$-D-galactosidase from Escherichia coli and horseradish peroxidase as labels by sandwich enzyme immunoassay technique. Ann Clin Biochem 21:310 317,1984 